\title{
ФАКТОРЫ ВОЗНИКНОВЕНИЯ СЛОВ С ИЗМЕНЁННОЙ СЕМАНТИЧЕСКОЙ СТРУКТУРОЙ
}

Афоніна Ю. М. Фактори виникнення слів зі зміненою семантичною структурою слова.

Статтю присвячено факторам виникнення слів зі зміненою семантичною структурою. В історії слів зазначені зміни можуть залишити подвійний наслідок. 3 одного боку, денотат може характеризуватися кількома сигніфікатами, об'єднаними компонентом переносу. 3 іншого, - модифіковане значення може стати єдиною мовною реальністю, закріпленою нормою сучасної російської мови, утративши початковий набір сем у складі семеми.

Ключові слова: семантичні зміни, денотат, сигніфікат, внутрішня форма слова, семантична структура слова.

Афонина Ю. Н. Факторы возникновения слов с изменённой семантической структурой.

Статья посвящена факторам возникновения слов с изменённой семантической структурой. В истории слов изменения такого рода могут оставить двоякий след. С одной стороны, один денотат может характеризоваться несколькими сигнификатами, объединенными компонентом переноса. С другой стороны, модифицированное значение может стать единственной языковой реальностью, закреплённой нормой ๑ Ю. Н. Афонина, 2014. 
современного языка, утратив первоначальный набор сем в составе семемы.

Ключевые слова: семантические изменения, денотат, сигнификат, внутренняя форма слова, семантическая структура слова.

Afonina J. N. Factors of words with the modified semantic structure.

The article is devoted to the factors of words altered semantic structure. In the history of words such changes can leave the dual track. On the one hand, a denotation can be characterized by several significatum that are united transfer part. On the other hand, the modified value may be the only linguistic reality that is fixed norm of the modern Russian language and lose the initial set of seeds as part sememe.

Key words: semantic changes, denotation, significatum, inner form ofa word, semantic structure of a word.

Когда речь идет о семантических факторах, приводящих к возникновению слов с изменениями в семантической структуре, нужно иметь в виду и соотношение этого процесса с традиционно выделяемыми типами семантических изменений: метафорическими, метонимическими переносами наименований, сужением и расширением семантического объема слова, конкретизацией и абстрагированием значений и т. д.

Нарушение смысловой соотносительности деривата с генеративом, ведущее к изменениям в семантической структуре слова, может быть вызвано расширением поля денотативного пространства производного слова, что сопровождается перегруппировкой сем (нарушением иерархической структуры семемы, её качественного и количественного преобразований) в структуре значения слова. Такой тип семантических изменений определяется как расширение сигнификата.

В работах многих лингвистов (Ю. Д. Апресян, Р. И. Гафарова, Ю. Н. Караулов, Дж. Лайонз, Л. А. Новиков, А. А. Уфимцева и др.) указано, что процесс расширения значения производного по денотату тесно связан с понятием гипонимической (периферийной) мотивации. Отношения гипонимической мотивации характеризуются тем, что семантика деривата связана с семантикой генератива лишь частью своего значения.

У существительного должнность - 'служебная обязанность' (через ступень должныц̌) от долг - 'моральное обязательство' (сначала только по отношению к богу; в результате расширения сигнификативного значения в семантической структуре произошла смена ведущих сем 'религиозный' $\rightarrow$ 'гражданский, общественный'. Как отмечает А. В. Бастриков, исследуя изменения значений слов с моральноэтической семантикой в русском литературном языке XVIII в., причина 
подобных трансформаций заключалась в переориентации в общественной жизни, когда на первый план выдвигалась идея служения государству, исполнение гражданского долга. Это привело к семантической дифференциации слов долг и долюсность 'служебная обязанность' [1, с. 7], вследствие чего набор сем, ориентированных на моральные качества, у слова должнность утратился.

По-видимому, подобная смена сем происходила при формировании значения слова повинность 'общественная или государственная обязанность населения' (через ступень повинный), образованного от слова вина 'проступок, преступление', осмысляемого в моральноэтическом плане. В результате расширения сигнификативного значения происходят изменения на понятийном уровне, что способствует изменениям в семантической структуре слова повинность. Расширение сигнификата обеспечивается, главным образом, за счёт наращения значения. Изначально доминирующее значение может становиться второстепенным или исчезать совсем.

Изменения в семантической структуре слова зависят также от процессов утраты внутренней формы, при которых происходит сужение сигнификата. Так как слово может быть наделено широким понятийным объёмом, то, функционируя, оно способно сузить свои семантические границы. Сужение объёма семантики слова, нередко его специализация способны привести к забвению первоначального значения, к изменениям в семантической структуре слова и к опрощению основы.

Например, слово оружие заимствовано из церковнославянского языка и сосуществовало с исконно русским ружювё (10, с. 154). При этом слова были абсолютными синонимами. Со временем семантический состав слова ружжвё изменился - произошло сужение сигнификата, что привело к затемнению внутренней формы. В современном русском языке существительное ружньё является конкретным и употребляется со значением: «Ручное огнестрельное оружие с длинным стволом» $(5$, с. 1132). Первоначально ружьё, также как и оружие, было собирательным и образовывалось при помощи суффикса -j- с отрицательно-эмоциональным значением. Поскольку оба слова утратили эту окраску, суффикс стал асемантичным. Вероятно, этому способствовала архаизация производящей основы ружж«хворост, ветка высохшего дерева», поэтому приставка о- в слове оружие тоже стала частью корня.

() Ю. Н. Афонина, 2014. 
Семантические изменения, при которых сужается семантический объём слова, часто происходят в результате конкретизации, специализации значения слова. Интерес в этом аспекте представляют терминологические изыскания доказывается, что конкретизация значения слова для выражения научного понятия может привести к «отпочковыванию нового слова со специализированным значением, к появлению семантического неологизма» [2, с. 24-25].

Думается, что этот процесс касается не только слов-терминов. Например, сужение сигнификата осуществлялось и в семантической структуре таких слов, как ж⿻алование «дарение чего-либо из любви без правого основания» $(9$, с. 35$) \rightarrow$ 'заработная плата' $(5$, с. 299); держава 'содержанье, уход, забота' [252, с. 400] $\rightarrow$ 'независимое государство, ведущее самостоятельную политику’ (6, с. 252); крепость 'мужество; клятва, присяга, бумага с каким-либо обязательством' $\rightarrow$ 'постройки, приспособления для укрепления чеголибо, а потом обороны населённых пунктов’ [3, с. 151-152]. Основы этих существительных опрощенные, поскольку слова в современном языке не соотносятся со своими мотиваторами.

Чаще всего сужение сигнификата происходит в результате трёх основных причин: 1) в языке одновременно функционируют два однокоренных синонимичных слова, тогда в случае появления новой реалии, денотативно соотносимой с синонимами, в одном из них происходит перераспределение сем: создаётся такой их набор, который способен отражать дифференциальные и интегральные признаки неназванной реалии; 2) лексема содержит эмотивный компонент, который предопределяет появление нового значения, потенциально способного стать доминирующим; 3) осуществляется специализация или терминологизация слова, требующая, во-первых, моносемичности, во-вторых, отсутствия экспрессии, в-третьих, стилистической нейтральности и т. д.

Процесс смены денотата может зависеть от фонетических преобразований. Исторически существительное число не имело отношения к счёту в современном его понимании и было родственно словам чumamb, честь, в праславянский период имело фонетический облик *čit-slo. В более поздние периоды согласный $[\boldsymbol{m}]$ подвергся диэрезе. Глаголы читать и считать являлись видовой парой, где первый глагол был несовершенного вида, а второй - совершенного. 
Постепенно семантика между ними изменилась: читать - «разбирать письмо, грамоту, писанное или печатное буквами» (7, с. 403), считать - «узнавать счётом число» (7, с. 136). Поэтому слово число семантически стало соотноситься с глаголом считать. Предположительно изначальное значение слова 'то, при помощи чего читали'. В современном русском языке это слово полисемично «1. Единица счёта, выражающая то или иное количество. 2. День месяца в порядковом ряду других дней. 3. Количество кого-, чеголибо. 4. Состав, ряд, совокупность кого-л., чего-л. 5. Лингв. Грамматическая категория, выражающая морфологическими средствами языка единичность или множественность предметов или лиц» (5, с. 1480). Если сравнить первоначальное и современное значения слова число, то обнаруживается семантический сдвиг.

Семантическим изменениям могут способствовать и мёртвые аффиксы, примером чего является слово свобода. Первоначально это существительное было собирательным и образовывалось при помощи мёртвого, с точки зрения современного русского языка, суффикса -од(a) (ср. современное сброд). Постепенно значение собирательности утратилось суффиксом, что привело к его асемантизации, а затем к семантическим изменениям. Сначала слово свобода стало означать 'независимость', а позже 'свободное поселение' (10, с. 582-583). Семантические изменения повлияли на эпидигматическую активность лексемы, и в современном русском языке полисемию свобода составляют 10 семем: «1. Отсутствие политического и экономического гнёта, отсутствие стеснений, ограничений в общественно-политической жизни общества. Свобода манифестаџий. 2. Государственная независимость, суверенитет. Сражаться за свободу своей Родиньл. 3. Отсутствие крепостной зависимости, рабства. Купить себе свободу. 4. Состояние того, кто не находится в заключении, в неволе. Лишение cвободы. 5. Отсутствие зависимости от кого-либо, возможность располагать собою по собственному усмотрению. Стеснять чью-либо свободу. 6. Чего и с инф. Возможность действовать какой-либо области без ограничений, запретов, беспрепятственно. Свобода торговли. 7. Филос. Возможность проявления субъектом своей воли на основе осознания законов развития природы и общества. Свобода есть осознанная необходимость. 8. Лёгкость, отсутствие затруднений в чёмлибо. Свобода манёвра. 9. Разг. Раздолье, простор. Берёза любит свободу. 10. Свободное, незанятое время; досуг. На свободе» (5, с. 1161). 


\section{СТРУКТУРА I СЕМАНТИКА МОВНИХ ОДИНИЦЬ}

С кон. ХX в. актуализируется два значения слова: «1. Возможность человека действовать в соответствии со своими интересами и целями; отсутствие зависимости. Акцентируя внимание на возрастании сексуальной свободы женщин, учёные единодушно связывают это явление с изменением их ролевого поведения в условиях современного общества: всё больше времени женщины проводят вне дома и имеют больше возможностей для общения. 2. Отсутствие ограничений, запретов. Даже возможное увеличение выездов и в определённой мере «утечка умов» не могут быть основанием для того, чтобы ставить под сомнение сам принции свободы выезда из своей страныл (8, с. 702 -703).

Одним из факторов, влияющих на возникновение семантических изменений в некоторых словах, является наличие или утрата словом метафорической мотивированности. В одних словах метафоризация способствует вытеснению основного значения, в других - образность метафорического наименования не всегда прочно закрепляется за словом. Оба случая нередко приводят к качественным изменениям в семантической структуре слова.

Такая тенденция характерна для общеупотребительных, нейтральных слов русского языка. Так, например, слово держава исторически родственно с глаголом держать и образовано от него при помощи суффикса -в-. Прямое значение слова держава - «предмет, который держат в руке». На базе основного (прямого) значения при помощи метафоризации развилось несколько переносных значений этого слова, вытеснивших основное на периферию, что зафиксировано в словаре В. И. Даля: «содержанье, уход, забота; \| кстр. Расход, потребление, издержка; $\|$ крепость, сила, прочность, твёрдая связь, надёжность в скрепе; || владычество, могущество; \|| за что можно держаться, ухватиться; поручни, ручка, рукоять, скоба или хватка; ॥ земля, государство, самостоятельное владенье, народ и правительство его; || одна из регалий, золотой шар с крестом наверху; царское яблоко. Купи муки на державу, на расход. ॥ Железная полоса, привариваемая временно к выковываемой крупной вещи, для держания её и управления ею на наковальне; железный прут вилами, употребляемый при сварке железа; подобный стержень для садки серебряных бликов (слитков) в плавильный горн» $(6$, с. 400$)$. Важно отметить, что В. И. Даль указывает на синонимичность слов держава и держа. Очевидно, слово держава употреблялось шире, чем слово держа, потому что в результате исторического развития слово держка стало 
историзмом. В свою очередь в слове держава осуществилось сужение сигнификата: «1. Независимое государство, ведущее самостоятельную политику. Европейские державы. Великие державы (наиболее крупные государства, обладающие большим экономическим и военным потенциалом). 2. Устар. Верховная власть; владычество. 3. Ист. Золотой шар с короной или крестом наверху как одна из эмблем власти монарха» $(5$, с. 252$)$. Изначально первичное значение переместилось на периферию, а образовавшиеся значения посредством метафоризации заняли доминирующую позицию. За последние 15 лет в связи с актуализацией первого значения слова в языке появились и такие слова, как державник - «тот, кто считает, что интересы государства превыше всего - выше общечеловеческих ценностей, прав человека и т. п. Коммунист Зюганов проповедует принципь, коренным образом расходящиеся с коммунистической идеологией: ратует за соборную правду, выступает «державником» $и$ «государственником», братается с лидером кадетов М. Астафьевым» - и сверхдержава «мощное в политическом, экономическом и военном отношении государство, оказывающее решающее влияние на международную жизнь (как правило, о США и СССР): Утратив, может бать, во благо себе и миру статус сверхдержавы, имевший в первую очередь военные измерения, Россия не утратила статуса великой мировой державы $и$ не собирается отказываться от него» $(8$, с. 217,701$)$.

Семантические изменения могут быть обусловлены и такими изменениями в семантике слова, как развитие абстрактного характера значения. При этом первоначальное «конкретное» значение вытесняется новым абстрактно-чувственным, а вместе с его исчезновением теряется и ощущение внутренней формы слова. Например, системные отношения, существующие в русском языке между отглагольными существительными и глаголами, обусловили то обстоятельство, что в современном языке существительное вдохновение осмысливается как образованное от глагола вдохновить. Здесь происходит то, что В.В. Виноградов называет смещением словообразовательных связей. Однако существительное вдохновение «творческое воодушевление, состояние творческого подъема» образовано не от глагола вдохновить, а от вдохнуть, которое в древнерусском языке могло иметь два значения: 1) действие по глаголу вдуть - 'вдыхание' 2) Перен. 'духовное внушение'. В дальнейшем существительное вдохновение утрачивает семантико-

() Ю. Н. Афонина, 2014. 
словообразовательные связи с глаголом вдохнуть. В. В. Виноградов, исследуя историю значения этого слова, отмечает, что семантическому разрыву этих слов способствовала быстрая смысловая эволюция слова вдохновение. Значение, имевшее религиозно-мистическую окраску, всё теснее связывается с представлением о творческом наитии, а глагол вдохнуть - вдыхать был отягчён конкретными бытовыми ассоциациями. Именно поэтому значение, связанное с семантикой глагола вдыхать, утрачивается, а вместе с его утратой затемняется истинная внутренняя форма слова вдохновение.

Таким образом, семантические изменения происходят при метафорическом и метонимическом переносах, расширении и сужении объёма значения производного слова, развитии абстрактного значения деривата. Основным условием для семантических изменений является нарушение семантических связей в ассоциативнодеривационном поле слов, утрата прежних коннотаций. При этом часто первичные, основные значения, имеющие ясную мотивировку, вытесняются вторичными, которые стали единственными значениями в современном языке.

\section{Литература}

1. Бастриков А. В. Изменение значений слов с морально-этической семантикой в русском литературном языке XVIII века : автореф. дис. ... канд. филол. наук : спец. 10.02.01 - русский язык / Алексей Васильевич Бастриков. - Л., 1989. - 17 с.

2. Даниленко В. П. Русская терминология. Опыт лингвистического описания / Валерий Петрович Даниленко. - М. : Наука, 1977 - 246 с.

3. Порохова О. Г. Заметки о новых словах в русском языке XV - XVII вв. / О. Г. Порохова // Исследования по лексикологии и грамматике русского языка. - М., 1961. - C. 151-152.

4. Потиха 3. А. Современное русское словообразование / Зиновий Аронович Потиха. - М. : Просвещение, 1970. - 384 с.

5. Большой толковый словарь русского языка / [гл. ред. С. А. Кузнецов]. - СПб. : «Норинт», 2004. - 1536 с.

6. Даль В. И. Толковый словарь живого великорусского языка : в 4 тт. / Владимир Иванович Даль. - М. : ОЛМА-ПРЕСС; ОАО ПФ «Красный пролетарий», 2004. - Т. 1. $-640 \mathrm{c}$.

7. Даль В. И. Толковый словарь живого великорусского языка : в 4 тт. / Владимир Иванович Даль. - М. : ОЛМА-ПРЕСС; ОАО ПФ «Красный пролетарий», 2004. - Т. 4. $-576 \mathrm{c}$.

8. Толковый словарь современного русского языка. Языковые изменения конца ХХ столетия / ИЛИ РАН ; [под. ред. Г. Н. Скляревской]. - М. : ООО «Издательство Астрель», 2001. - 944 с.

9. Фасмер М. Этимологический словарь русского языка : в 4 тт. / Макс Фасмер ; 
[пер. с нем. и доп. О. Н. Трубачёва]. - [4-е изд.]. - М. : ООО «Издательство Астрель», 2003. - T. 2. $-2003 .-672$ c.

10. Фасмер М. Этимологический словарь русского языка : в 4 тт. / Макс Фасмер ; [пер. с нем. и доп. О. Н. Трубачёва]. - [4-е изд.]. - М. : ООО «Издательство Астрель» : ООО «Издательство АСТ», 2003. - Т. 3. - 832 с.

Стаття надійшла до редакиії 14.09.2014 p. 